\title{
ANALISIS PENGARUH STABILITAS POLITIK DAN FAKTOR EKONOMI TERHADAP INDEKS HARGA SAHAM GABUNGAN
}

\author{
Abdul Basit \\ Fakultas Ekonomi Dan Bisnis Islam (FEBI) \\ Universitas Islam Negeri (UIN) Sunan Kalijaga Yogyakarta \\ abdbasit688@gmail.com \\ Slamet Haryono \\ Fakultas Ekonomi Dan Bisnis Islam (FEBI) \\ Universitas Islam Negeri (UIN) Sunan Kalijaga Yogyakarta \\ slamet.haryono@uin-suka.ac.id
}

Article History:

Received: 6 Januari 2021

Revised: 28 April 2021

Accepted: 28 April 2021
Abstract : The data used in this study are the Composite Stock Price Index data which is consistently included in the IDX during the study period, namely 2010-2019, the economic factors used are the exchange rate, inflation rate, and data on Indonesia's political stability during the period 2010-2019. The author uses the panel data regression method supported by quantitative analysis using an econometric model to get a clear picture of the relationship between the variables used in the study. This research was conducted to see the influence of economic factors, exchange rates, inflation and political stability on the Composite Stock Price Index in the period 20102019. The results of this study are the Exchange Rate Variable has a significant negative effect on the Composite Stock Price Index on the IDX. Inflansi variables have a positive and insignificant effect on the Composite Stock Price Index on the IDX. The ISP variable has a significant positive effect on the Composite Stock Price Index on the IDX. Exchange rate data, inflation are obtained from Bank Indonesia publications. The Indonesian Political Stability data were obtained from The Global Economy.com, The World Bank.

Abstrak: Data yang digunakan dalam penelitian ini adalah data Indek Harga Saham Gabungan yang konsisten masuk di BEI pada periode penelitian, yaitu tahun 2010-2019, Faktor Ekonomi yang di gunakan adalah nilai Tukar, Nilai inflasi, dan data stabilitas politik Indonesia selama periode tahun 2010-2019. Penulis menggunakan metode regresi data panel dengan didukung oleh analisis kuantitatif 
dengan menggunakan model ekonometrik untuk mendapatkan gambaran yang jelas tentang hubungan antara variabel-variabel yang digunakan dalam penelitian. Penelitian ini dilakukan untuk melihat pengaruh faktor-faktor ekonomi, Nilai Tukar, Inflasi dan stabilitas politik terhadap Indek Harga Saham Gabungan pada periode tahun 2010-2019. Hasil penelitian ini adalah Variabel Nilai Tukar berpengaruh Negatif signifikan terhadap Indeks Harga Saham Gabungan di BEI. Variabel inflansi berpengaruh positif tidak signifikan terhadap Indek Harga Saham Gabungan di BEI. Variabel Indeks Stabilitas Politik (ISP) berpengaruh positif signifikan terhadap Indek Harga Saham Gabungan di BEI. Data Nilai Tukar, inflasi diperoleh dari publikasi Bank Indonesia. Adapun data Stabilitas Politik Indonesia diperoleh dari The Global Economy.com, The World Bank.

Keywords: Politics, Economic Factors and IHSG

Kata Kunci: Politik, Faktor Ekonomi dan IHSG

\section{PENDAHULUAN}

Dalam pasar modal yang efisien, pasar akan bereaksi cepat terhadap semua informasi yang relevan. Jika informasinya positif, itu akan berdampak positif pada harga saham, sebaliknya jika informasinya negatif, itu akan berdampak negatif pada harga saham. Pasar saham secara historis memiliki siklus, terus bergerak melalui puncak siklus yang matang. Siklus ini telah dikaitkan dengan banyak perbedaan secara historis termasuk siklus Pemilihan Presiden(Marcelin, 2018). Konteks pemilihan presiden, berdampak pada perekonomian dan pasar keuangan. Waktu pemilihan bukanlah ukuran langsung dari ketidakpastian politik, itu penting untuk mengasumsikan bahwa ketidakpastian politik memang lebih tinggi secara rata-rata pada periode menjelang pemilihan dibandingkan dengan periode waktu lainnya. Peristiwa-peristiwa politik merupakan salah satu bagian dari lingkungan non ekonomi yang dapat berpengaruh pada kondisi pasar modal, karena dinamika situasi politik pada dasarnya juga berkaitan dengan stabilitas perekonomian suatu Negara. Adanya kemungkinan munculnya pemimpin baru membuat para pelaku pasar menaruh ekspektasi khususnya terkait kemajuan perekonomian di tangan pemimpin baru tersebut (Eichler, 2020). Apabila pemimpin baru dapat membawa perubahan yang positif bagi ekonomi melalui berbagai strategi, kebijakan, serta gebrakan yang inovatif, maka tidak menutup kemungkinan bahwa perubahan positif itu juga dapat berkontribusi bagi peningkatan perekonomian Indonesia. Saham pada umumnya berkinerja buruk pada tahun-tahun pemilihan dibandingkan dengan tahun-tahun 
non-pemilihan. Ada perbedaan yang jelas dalam pemilu dengan tahun non-pemilu dan bahkan lebih diperburuk pada waktu pemilu. peningkatan ketidakpastian politik memiliki efek signifikan pada pasar saham dan volatilitas harga saham dan sinkronisitasnya (Leherr, 2019).

Peran penting pemilu sebagai peristiwa politik besar yang mendistribusikan kembali kekuasaan politik berimplikasi pada lingkungan politik dan ekonomi masa depan suatu negara. Secara khusus, ketidakpastian politik selama masa pemilihan mendorong volatilitas harga saham dan pasar keuangan seperti yang telah dibahas sebelumnya, karena faktor-faktor seperti demokrasi yang lemah, pelayanan publik yang buruk, ketidakstabilan politik, dan korupsi yang tinggi serta perlindungan hak milik yang rendah, rendah kualitas tata kelola tingkat negara sering dianggap sebagai akar penyebab dari bank yang kurang spesifik (Kun-Li Lin, 2020). Stabilitas politik yang diikuti dengan kestabilan kondisi ekonomi, akan membuat para investor merasa aman untuk menginvestasikan dananya di pasar modal. Investor umumnya akan menaruh ekspektasi terhadap setiap peristiwa politik yang terjadi dan ekspektasi mereka akan tercermin pada fluktuasi harga ataupun aktivitas volume perdagangan saham di bursa efek. Hal ini terus berdampak besar pada industry Secara keseluruhan dan ketidakpastian menyebabkan investor mengambil modal dari saham-saham yang ada tersebut secara historis dianggap sebagai investasi yang aman dan defensive. Investor di pasar modal didominasi oleh investor asing pengaruh politik tersebut peristiwa dapat menyebabkan fluktuasi yang tinggi antara harga awal saham dan pengaruh harga saat ini (Gunay, 2016). Penggunaan kualitas tata kelola tingkat negara sebagai proxy untuk peran kelembagaan lingkungan dalam menentukan informasi secara spesifik, Literatur yang muncul di pengembangan kelembagaan telah menyoroti bagaimana variasi dalam kualitas lembaga yang menyebabkan variasi sinkronisitas dari harga saham (Anh-Tuan Doan, 2020).

Setelah mengontrol efek publik informasi perubahan sinkronisitas harga saham mencerminkan bagaimana upaya untuk pengumpulan informasi pribadi oleh investor, Karena informasi pribadi segera tercermin dalam harga saham melalui perdagangan, perusahaan dengan konsentrasi kepemilikan yang lebih tinggi untuk negara maju, kami menemukan bahwa pasar saham menghargai pembubaran pemerintah terkait dengan rasio investasi terhadap PDB yang relatif rendah. Pergeseran ke yang lebih tinggi untuk rasio investasi di bawah pemerintahan baru mungkin menandakan prospek pertumbuhan ekonomi yang lebih tinggi, sehingga arus kas masa depan yang lebih tinggi untuk perusahaan yang mendapatkan keuntungan dari saham (Stefan Eichler dan Timo Plaga 2020). Secara umum, ini ditunjukkan dengan perubahan harga saham yang melebihi kondisi normal, sehingga menimbulkan pengembalian abnormal. Selain menggunakan pengembalian abnormal, reaksi pasar 
saham terhadap informasi bisa juga dapat dilihat melalui parameter pergerakan aktivitas perdagangan di pasar (Trading Volume Activity), dimana jika sebuah investor menilai suatu peristiwa yang mengandung informasi maka acara tersebut akan menghasilkan keputusan perdagangan (Magdalena, 2019).

Volatilitas ekstrim terjadi di sekitar waktu ketidakpastian yang signifikan, misalnya pemilu nasional. Investor tidak dapat membuat kesimpulan tentang masa depan dan peningkatan perdagangan Pada tahun-tahun pemilu, ada peningkatan signifikan dalam volume perdagangan Ini adalah tren yang sangat terlihat jelas setiap siklus pemilihan dipelajari (Lee, 2020). Untuk menggerakkan volume dalam menanggapi perkembangan tersebut (Jake Yennaco, 2020). Ketidakpastian tentang masa depan mungkin membuat perekonomian lebih sulit untuk dimasukkan ke dalam harga saat ini, menciptakan volatilitas yang lebih besar dalam keuangan. Salah satu sumber ketidakpastian yang potensial adalah hasil pemilu nasional. Jika berbeda calon presiden dikaitkan dengan peraturan dan kebijakan fiskal yang kontras, kemudian para pelaku pasar keuangan mungkin memiliki pandangan yang berbeda tentang kinerja ekonomi di masa depan tergantung pada pemenang akhirnya (David R Bowes, 2018)

Pasar modal memiliki peranan yang sangat penting dalam perekonomian global saat ini. sudah sepatutnya memaksimalkan peran pasar modal dalam perekonomian global, baik sebagai tempat untuk menghimpun dana, tempat alternatif investasi melalui penjualan saham dan penerbitan obligasi, maupun sebagai indikator stabilitas kondisi makroekonomi (David R Bowes, 2018). Perkembangan saham yang mengalami peningkatan signifikan tentu dipengaruhi oleh berbagai faktorfaktor penting yang mampu mempengaruhi perkembangan saham, diantaranya adalah variabel makroekonomi dan moneter seperti salah satunya adalah inflasi dan lain-lain. Adapun faktor non ekonomi yang mempengaruhi adalah kondisi keamanan nasional, kondisi politik, kebijakan pemerintah dan lain-lain (Magdalena, 2019). Perubahanperubahan yang terjadi pada faktor ini dapat mengakibatkan perubahanperubahan di pasar modal, yaitu meningkat atau menurunnya harga saham yang kemudian berpengaruh terhadap indeks harga saham, Inflasi sebagai indikator makroekonomi mempunyai pengaruh terhadap tingkat investasi (David R Bowes, 2018). Tingkat inflasi dapat berpengaruh positif maupun negatif terhadap perekonomian, tergantung pada derajat inflasi itu sendiri. Inflasi yang berlebihan dapat merugikan perekonomian. Keberadaan pasar modal diharapkan dapat meningkatkan aktivitas perekonomian. Hal ini disebabkan pasar modal merupakan salah satu alternatif pendanaan bagi perusahaan sehingga dapat beroperasi dengan skala yang lebih besar dan selanjutnya akan meningkatkan pendapatan perusahaan dan kemakmuran masyarakat luas. (Magdalena, 2019) 
Peran pasar modal sangat besar bagi perekonomian suatu negara, karena modal pasar menjalankan dua fungsi pada saat waktu yang sama, fungsi ekonomi dan keuangan fungsi. Pasar modal dikatakan memiliki fungsi ekonomi karena pasar modal menyediakan fasilitas atau kendaraan yang mempertemukan dua kepentingan, yaitu itu dengan dana berlebih (investor) dan mereka yang butuh dana (Lee, 2020). Adanya sebuah investor dapat menginvestasikan dananya diharapkan dapat memperoleh hasil, sedangkan pihak yang membutuhkan dana dapat memanfaatkan dana tersebut untuk keperluan investasi tanpa harus tunggu ketersediaan dana dari operasi perusahaan. Pasar modal adalah dikatakan memiliki fungsi keuangan, karena itu memberikan kemungkinan dan kesempatan untuk memperoleh keuntungan bagi pemilik dana sesuai dengan karakteristik investasi yang dipilih. (Magdalena, 2019)

Pemerintah politik yang berkuasa setelah mendapatkan suara dari publik akan menguasai basis pemilihan. Kenapa pemilu ini menjadi sangat penting terkait berubahnya harga saham dan arah investasi para investor? Karena, para investor tentu hanya akan berinvestasi pada saham-saham yang memiliki return yang tinggi dan memiliki prospek yang bagus dimasa depan (Lee, 2020) Mereka akan cenderung menjual atau membeli saham yang diprediksi sangat menguntungkan bagi mereka dengan mempertimbangkan berbagai informasi dan peristiwa yang ada. (Magdalena, 2019) dalam penelitian ditemukan bukti bahwa pemerintahan otokratis cenderung menciptakan volatilitas yang lebih besar dalam pertumbuhan ekonomi dalam jangka panjang dan di sisi lain situasi stabil dalam kinerja ekonomi jangka panjang Marcelin, 2018). Studi ini meneliti tentang Analisis Pengaruh Stabilitas Politik (Pemilu Presiden ) dan Faktor Ekonomi Terhadap Indeks Harga Saham Gabungan. Selain itu, terbatasnya penelitian yang menganalisis pengaruh faktor politik juga menjadi salah satu alasan mengapa penelitian ini penting untuk dilakukan yang di mana penelitan ini akan melihat bagamana pengruh dari pemilu presiden tersebut.

\section{KAJIAN TEORI}

\section{Pasar modal}

Pasar Modal merupakan alternatif penghimpunan dana selain sistem perbankan. Menurut Suad (1994), pasar modal adalah pasar dari berbagai instrumen keuangan (sekuritas) jangka panjang yang dapat diperjual belikan, baik dalam bentuk hutang (obligasi) maupun modal sendiri (saham) yang diterbitkan pemerintah dan perusahaan swasta. Sedangkan undang-undang Republik Indonesia Nomor 8 Tahun 1995 Tentang Pasar Modal memberikan pengertian pasar modal sebagai suatu kegiatan yang bersangkutan dengan Penawaran Umum dan perdagangan Efek, Perusahaan Publik yang berkaitan dengan Efek yang diterbitkannya, serta lembaga dan profesi yang berkaitan dengan Efek (Bapepam.go.id, 
2006). Pengertian lainnya, pasar modal adalah salah satu sumber pembiayaan eksternal jangka panjangbagi dunia usaha khususnya perusahaan yang go public dan sebagai wahana investasi bagi masyarakat (Farid, 1998).

\section{Teori Ekonomi Politik}

Menurut Caporaso (1992) pemaknaan terhadap ekonomi politik tidak terbatas pada studi tentang teori sosial dan keterbelakangan. Pada awalnya ekonomi politik dimaksudkan untuk memberi saran mengenai pengelolaan masalah ekonomi kepada penyelenggara negara. Ekonomi politik oleh pakar Ekonomi Politik Baru lebih diartikan sebagai analisis ekonomi terhadap proses politik. Dalam hal ini mereka mempelajari institusi politik sebagai keberadaan yang bersinggungan dengan keputusan ekonomi politik yang berusaha memengaruhi pengambilan keputusan dan pilihan publik, baik untuk kepentingan kelompoknya atau masyarakat.

Menurut Arifin dkk (2001) ekonomi politik lahir dari berbagai upaya yang dilakukan utuk menemukan sinergi, mengisi kekosongan yang tidak dijumpai dalam satu displin atau disiplin politik saja. Penggabungan antara ekonomi dan politik sangat diperlukan, jika kita berbicara mengenai ilmu ekonomi atau ilmu politik saja secara terpisah, maka kita akan mengalami kesulitan dalam menjelaskan gejala dan masalah yang dihadapi secara nyata dalam interaksinya.

\section{Nilai Tukar}

Nilai Tukar merupakan salah satu harga yang terpenting dalam perekonomian terbuka mengingat pengaruh yang demikian besar bagi neraca transaksi berjalan maupun variabel-variabel makro ekonomi yang lain. Ada dua pendekatan yang digunakan untuk menentukan nilai tukar mata uang yaitu pendekatan moneter dan pendekatan pasar. Dalam pendekatan moneter, nilai tukar mata uang di definisikan sebagai harga dimana mata uang asing diperjual belikan terhadap mata uang domestik dan harga tersebut berhubungan dengan penawaran dan permintaan uang (Magdalena, 2019). Naik turunnya nilai tukar mata uang atau kurs valuta asing bisa terjadi dengan berbagai cara, yakni bisa dengan cara dilakukan secara resmi oleh pemerintah suatu negara yang menganut sistem managed floating exchange rate, atau bisa juga karena tarik menariknya kekuatan-kekuatan penawaran dan permintaan di dalam pasar market mechanism (Achmad Ath, 2009) 


\section{Inflansi}

Inflasi adalah kenaikan harga barang-barang yang bersifat umum dan terus menerus (Rahardja dan Manurung, 2008). Definisi tersebut memberikan makna bahwa kenaikan harga barang tertentu tidak termasuk inflasi. Syarat adanya kenaikan harga secara terus menerus perlu diperhatikan. Kenaikan harga-harga karena musiman, menjelang hari raya,bencana, dan sebagainya yang sifatnya hanya sementara tidak disebut inflasi. Ukuran inflasi yang paling banyak digunakan adalah Indeks Harga Konsumen. Indeks ini berdasarkan pada harga dari satu paket barang yang dipilih dan mewakili pola pengeluaran konsumen.

\section{Indeks Harga Saham}

Seiring dengan meningkatnya aktivitas perdagangan, kebutuhan untuk memberikan informasi yang lebih lengkap kepada masyarakat mengenai perkembangan bursa juga semakin meningkat. Salah satu informasi yang diperlukan tersebut adalah harga saham sebagai cerminan dari pergerakan harga saham. Indeks harga saham merupakan indikator utama yang menggambarkan pergerakan harga saham (Achmad, 2009).

\section{Indeks Harga Saham Gabungan (IHSG)}

Indeks Harga Saham Gabungan Menurut Jogiyanto (2010) adalah suatu indikator yang dapat menunjukkan pergerakan harga saham yang berfungsi sebagai indikator pasar yang artinya pergerakan indeks-indeks menggambarkan kondisi pada suatu saat apakah pasar sedang aktif atau lemah. Faktor-faktor yang mempengaruhi Indeks Harga Saham Gabungan adalah adalah surat berharga atas unjuk dalam rupiah yang diterbitkan oleh Bank Indonesia sebagai pengakuan hutang berjangka waktu pendek dengan sistem diskonto.

\section{Indeks Stabilitas Politik}

Indeks Stabilitas Politik (Political Stability Index) adalah indeks yang mengukur stabilitas suatu negara, standar pemerintahan yang baik, catatan tatanan konstitusional, penghormatan terhadap Hak Asasi Manusia (HAM), dan kekuatan demokrasi secara keseluruhan. Indeks ini diterbitkan oleh World Bank. Indeks Stabilitas Politik ini dihitung berdasarkan catatan transisi kekuasaan yang berlaku di suatu negara, kemampuan pemerintah untuk melaksanakan kebijakannya. Indeks ini mengukur dinamika antara kualitas pemerintah suatu negara dan ancaman yang dapat membahayakan dan melemahkan stabilitas. Ancaman yang dimaksud di sini di antaranya adalah kudeta, ketidakstabilan, terorisme, dan lain-lain (Wahid, 2018) 


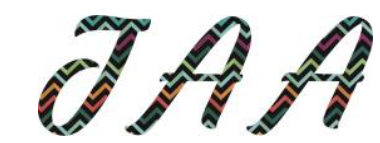

Vol. 5, No. 2, April 2021

\section{PENELITIAN DAHULU}

Penelitian terdahulu memberi gambaran dan kerangka pemikiran dalam penelitian maka perlu kiranya untuk membahas hasil-hasil penelitian terdahulu sebagai acuan dalam membandingkan penelitian saat ini dengan penelitian terdahulu sehingga akan menghasilkan suatu analisa yang sesuai dengan teori.

Eichler dkk (2020) Tujuan penelitian ini untuk menyelidiki peran catatan fiskal dan ekonomi petahanan pemerintah dalam membentuk respon harga obligasi berdaulat dan saham terhadap pemilu di pasar negara berkembang dan negara maju. Untuk obligasi berdaulat di negara berkembang pasar, kami menemukan bukti kuat untuk pengembalian abnormal kumulatif (CAR) yang lebih tinggi jika pemerintah yang terkait dengan keseimbangan fiskal primer yang relatif rendah dipilih di luar jabatannya dibandingkan dengan pemilu di mana keseimbangan fiskal relatif tinggi. Efek dari catatan fiskal pemerintah petahana secara signifikan lebih jelas di hadapan risiko default berdaulat tinggi dan pemain veto politik yang kuat, sedangkan kualitas institusi tidak menjelaskan perbedaan efek untuk acara yang berbeda. Kami tidak menemukan kuat dampak dari catatan fiskal pemerintah untuk negara maju dan saham.

Kami tidak menemukan atau lemahnya bukti untuk indikator ekonomi lain seperti peringkat, Karena masalah multicollinearity, kami tidak memasukkan utang pemerintah ke PDB sebagai variabel kontrol. pertumbuhan ekonomi, atau neraca transaksi berjalan, sedangkan inflasi tampaknya berperan pasar obligasi berdaulat di pasar negara berkembang. Untuk pasar negara berkembang, kami memberikan wawasan tentang relevansi faktor-faktor yang mempengaruhi evaluasi investor obligasi berdaulat terhadap hasil pemilu. Peran catatan fiskal pemerintah petahana untuk reaksi harga obligasi berdaulat adalah secara signifikan lebih kuat di hadapan tingkat risiko gagal bayar berdaulat yang relatif tinggi dan kendala politik, sedangkan kualitas lembaga tidak secara signifikan mempengaruhi respon pasar. Untuk pasar obligasi berdaulat di negara maju dan pasar saham secara umum, kami tidak menemukan bukti yang kuat untuk efek dari catatan fiskal pemerintah petahana di sekitar Pemilihan.

Liu dkk (2020) Tujuan ini termasuk Keinginan Belarus untuk mengurangi ketergantungannya pada gas dan minyak Rusia, meningkatkan dan mendiversifikasi ekonominya, memperkuat integrasi dengan Eurasia dan menemukan mitra baru, dengan menarik investasi langsung Cina dan asing lainnya di konteks Inisiatif Keluar dan Sabuk dan Jalan (BRI) Tiongkok. Analisis peran pemimpin nasional Aliaksandr Lukashenka dan Xi Jinping dan berbagai pemangku kepentingan dalam desain yang didominasi top-down, pengembangan dan tata kelola taman mengungkapkan cara platform kerjasama BRI mengizinkan konektor kepentingan dan strategi Cina dan Belarusia dengan cara yang diharapkan 
masing-masing pihak untuk mendapatkan manfaat. cant efek harga. Kami tidak menemukan atau lemahnya bukti untuk indikator ekonomi lain seperti peringkat, Karena masalah multicollinearity, kami tidak memasukkan utang pemerintah ke PDB sebagai variabel kontrol.

Hasil kami menyoroti keseimbangan fiskal primer sebagai indikator terpenting yang memprediksi bagaimana investor menilai catatan ekonomi pemerintah. Kami menemukan bukti kuat bahwa kumulatif abnormal imbal hasil obligasi berdaulat emerging market merespons secara signifikan lebih positif jika pemerintah yang terkait dengan neraca fiskal yang relatif rendah diganti dibandingkan jika keseimbangan tinggi. Setelah catatan keseimbangan fiskal yang tinggi, kami tidak mendeteksi signifi Pengembangan bersama oleh Belarus dan Cina dari Great Stone Industrial Park (GSIP) dirancang untuk zona industri berteknologi tinggi dan kota satelit Minsk yang ramah lingkungan sebagai simpul kunci di Jembatan Tanah Eurasia menghubungkan Tiongkok dengan Uni Ekonomi Eurasia dan Uni Eropa. Pengembangan dan organisasi GSIP dijelaskan dalam rangka kopling tujuan strategis kedua negara dalam konteks Model keterlibatan eksternal Tiongkok disebut budaya ekonomi geo-politik yang muncul.

Marcelin dkk (2018) Penelitian ini melihat sensitivitas investasi terhadap ketidakpastian pemilu dari 1990 hingga 2011 menggunakan sampel 2106 perusahaan dari 45 Negara. Ini memperluas literatur dengan mempelajari efek dari berbagai jenis pemilu, rezim politik, pada kelas aset yang berbeda. Itu menunjukkan bahwa pemilu, terlepas dari jenis mana, menyebabkan investasi disesuaikan ke bawah. Namun demikian, presiden bersama dan pemilihan legislatif memiliki efek negatif yang sama kuatnya terhadap investasi sebagai pemilihan parlemen dalam hal besarannya.

Hasil juga menunjukkan bahwa perusahaan membatasi pengeluaran investasi pada tahun menjelang pemilihan dan melanjutkan investasi pada tahun tersebut setelah pemilihan nasional. Hasilnya juga menunjukkan bahwa manajemen lebih cenderung mengadopsi strategi wait-and-see ketika dihadapi dengan ketidakpastian elektoral yang diinduksi oleh pemilihan umum. Selain itu, hasil penelitian menunjukkan bahwa sementara perusahaan memangkas kembali belanja investasi dalam aset tetap sekitar 2,3\% selama tahun pemilu dan hingga 4,43\% dalam pemilihan presiden dan legislatif bersama tahun, investasi dalam aset tidak berwujud tertekan oleh sekitar $4,47 \%$ pada tahun pemilihan parlemen. Hasilnya menunjukkan realitas di mana manajemen perusahaan menjadi lebih peduli dengan ketidakpastian yang ditimbulkan oleh pemilihan presiden dan legislatif bersama dan pemilihan parlemen.

\section{METODE PENELITIAN}

Penelitian ini dilakukan untuk melihat pengaruh, Nilai Tukar, Inflasi dan stabilitas politik terhadap Indek Harga Saham Gabungan pada periode 
tahun 2010-2019. Saham yang diteliti adalah saham yang konsisten masuk Indek Harga Saham Gabungan pada periode penelitian (tahun 2010-2019), yaitu AALI (Astra Agro Lestari Tbk.), INDF (Indofood Sukses Makmur Tbk.), TLKM (PT. Telekomunikasi Indonesia, Tbk), dan UNVR (PT. Unilever Indonesia, Tbk). Adapun stabilitas politik dalam penelitian ini menggunakan data Political Stability Index (PSI).

Data yang digunakan dalam penelitian ini adalah data Indek Harga Saham Gabungan yang konsisten masuk di BEI pada periode penelitian, yaitu tahun 2010-2019, nilai Tukar, Nilai inflasi, dan data stabilitas politik Indonesia selama periode tahun 2010-2019. Data yang digunakan adalah data tahunan. Alasan pemilihan periode tahun tersebut adalah untuk melihat pergerakan Indek Harga Saham Gabungan dan faktor yang mempengaruhinya secara lebih akurat dan relevan selama sepuluh tahun terakhir. Data harga saham yang digunakan diperoleh dari yahoo.finance.com. Data Nilai Tukar, inflasi diperoleh dari publikasi Bank Indonesia. Adapun data Stabilitas Politik Indonesia diperoleh dari The Global Economy.com, The World Bank.

Metode sampling yang digunakan adalah metode Purposive Sampling yaitu penelitian yang pengumpulan datanya atas dasar strategi kecakapan atau pertimbangan pribadi semata. Dalam penelitian ini data Indek Harga Saham Gabungan yang digunakan adalah data Indek Harga Saham Gabungan yang konsisten masuk BEI selama periode penelitian (2010 sampai 2019), yaitu AALI (Astra Agro Lestari Tbk.), INDF (Indofood Sukses Makmur Tbk.), TLKM (PT. Telekomunikasi Indonesia, Tbk), dan UNVR (PT. Unilever Indonesia, Tbk).

Metode Analisis Data Untuk menjawab permasalahan penelitian yang diajukan, maka dalam penelitian ini penulis menggunakan metode regresi data panel dengan didukung oleh analisis kuantitatif dengan menggunakan model ekonometrik untuk mendapatkan gambaran yang jelas tentang hubungan antara variabel-variabel yang digunakan dalam penelitian.

Data panel dianalisis dengan menggunakan tiga model yaitu Common Effect, Fixxed Effect, dan Random Effect. Ada dua tahap untuk mendapatkan model terbaik. Pertama, uji dengan membandingkan antara metode fixed effect dengan common effect yang disebut dengan uji signifikansi fixed effect. Kedua, yaitu dengan melakukan uji membandingkan antara metode fixed effect dengan random effect yang disebut uji Hausman. Secara umum dalam memilih model regresi data panel mana yang terbaik maka harus menggunakan dua pengujian diantaranya ada uji $\mathrm{F}$ dan uji Hausman. Jika pengujian tahap pertama mendapatkan hasil bahwa model common effect adalah model yang terbaik maka pengujian cukup pada tahap pertama, yaitu dimana metode analisisnya menggunakan metode common effect. Tetapi jika hasilnya adalah model fixed effect adalah model yang terbaik maka akan 
dilanjutkan pada tahap yang ke dua, yaitu membandingkan antara metode fixed effect dengan metode random effect. Kemudian, setelah pengujian tahap kedua selesai dan mendapatkan hasil bahwa metode fixed effect model yang lebih baik maka menggunakan metode fixed effect, sebaliknya pula jika hasilnya model random effect adalah model yang lebih baik (Sriyana, 2014). Selain menggunakan tiga model analisis diatas, peneliti juga melakukan pengujian statistik diantaranya yaitu Koefisien Determinasi (R2), pengujian koefisien regresi secara bersama-sama (Uji Fstatistik), dan pengujian koefisien regresi secara individul (Uji t-statistik). Atas dasar beberapa uji yang telah dilakukan oleh peneliti dengan menggunakan uji chow dan uji hausman, maka model Fixed Effect Model merupakan model yang layak digunakan untuk estimasi akhir yaitu Fixed Effect Models (Hasan, 2016)

\section{HASIL DAN PEMBAHASAN}

Penelitian ini membahas tentang pengaruh Analisis Stabilitas Politik (Pemilu Presiden) dan Faktor Ekonomi Terhadap Indek Harga Saham Gabungan. Dalam penelitian ini didapatkan bahwa variabel Nilai Tukar, ISP, berpengaruh signifikan terhadap Indek Harga Saham Gabungan di BEI. Sedangkan varuabel Inflansi, tidak berpengaruh signifikan terhadap harga saham di BEI. Sebagaimana telah dijelaskan sebelumnya regresi data Panel dengan menggunakan model Common effect, fixed effect, dan random effect. Langkah selanjutnya adalah memilih model terbaik yang akan digunakan. Pemilihan model dilakukan dengan dua tahap yaitu pertama uji chow dan kedua uji hausman. Uji chow dilakukan untuk menentukan model terbaik antara Common effect atau fixed effect. Sedangkan uji hausman dilakukan untuk menentukan model terbaik antara fixed effect atau random effect. adapun hasil uji chow adalah sebagai berikut:

Tabel 1 Hasil Uji Chow

\begin{tabular}{|c|c|c|c|}
\hline Effects Test & Statistic & d.f. & Prob. \\
\hline Cross-section F & 221.017098 & $(3,33)$ & 0.0000 \\
\hline $\begin{array}{c}\text { Cross-section } \\
\text { Chi-square }\end{array}$ & 121.956632 & 3 & 0.0000 \\
\hline
\end{tabular}

Sumber: Data Diolah: Eviews 2020

Tabel 1 hasil pengujian antara Common dan Fixed menggunakan Uji Chow Test, bahwa didapatkan nilai probabilitas sebesar $0.0000<0.05$ persen yang artinya signifikan, sehingga model yang terbaik digunakan adalah Fixed Effect Model. Langkah selanjutnya adalah menentukan model terbaik antara fixed effect dan random effect melalui uji hausman. Berikut hasil uji hausman. 
Tabel 2 Hasil Uji Hausman

\begin{tabular}{|c|c|c|c|}
\hline Test Summary & $\begin{array}{c}\text { Chi-Sq. } \\
\text { Statistic }\end{array}$ & Chi-Sq. d.f. & Prob. \\
\hline $\begin{array}{c}\text { Cross-section } \\
\text { random }\end{array}$ & 0.000000 & 3 & 1.0000 \\
\hline
\end{tabular}

Sumber: Data Diolah: Eviews 2020

tabel 2 hasil pengujian antara Fixed Effect Model menggunakan Uji Hausman, bahwa didapatkan nilai probabilitas sebesar $1.0000>0.05$ persen yang artinya tidak signifikan, sehingga model yang terbaik yang digunakan adalah Randem Efect Model. Langkah selanjutnya adalah menentukan model terbaik antara Comon Efect dan Random Efect melalui Uji Lagrange Multiplier. didapatkan nilai Both sebesar $0.0054<0.05$ persen yang artinya signifikan, sehingga model yang terbaik yang digunakan adalah Fixed Efect Model karena nilai Both lebih kecil dari 0.0005 .

\section{Hasil Pengujian Regresi}

\begin{tabular}{|c|c|c|c|c|}
\hline Variable & Coefficient & Std. Error & t-Statistic & Prob. \\
\hline $\mathrm{C}$ & -2.997252 & 2.607014 & -1.149688 & 0.2585 \\
\hline NILAI TUKAR & -1.255034 & 0.362371 & 3.463396 & 0.0015 \\
\hline INFLANSI & 1.862315 & 2.997383 & 0.621314 & 0.5387 \\
\hline \multirow[t]{2}{*}{ ISP } & 0.067285 & 0.014921 & 4.509454 & 0.0001 \\
\hline & \multicolumn{2}{|c|}{ Effects Specification } & & \\
\hline \multirow{2}{*}{\multicolumn{5}{|c|}{ Cross-section fixed (dummy variables) }} \\
\hline & & & & \\
\hline R-squared & 0.958703 & \multicolumn{2}{|c|}{ Mean dependent var } & 8.380000 \\
\hline Adjusted R-squared & 0.951195 & \multicolumn{2}{|c|}{ S.D. dependent var } & 1.544919 \\
\hline S.E. of regression & 0.341302 & \multirow{2}{*}{\multicolumn{2}{|c|}{ Akaike info criterion }} & 0.845530 \\
\hline Sum squared resid & 3.844071 & & & 1.141084 \\
\hline Log likelihood & -9.910592 & \multicolumn{2}{|c|}{$\begin{array}{l}\text { Schwarz criterion } \\
\text { Hannan-Ouinn criter. }\end{array}$} & 0.952393 \\
\hline F-statistic & 127.6825 & \multicolumn{2}{|c|}{ Durbin-Watson stat } & 0.809569 \\
\hline Prob(F-statistic) & 0.000000 & & & \\
\hline
\end{tabular}

Sumber: Data Diolah: Eviews 2020

Tabel 3 merupakan hasil dari pengujian variabel independen yaitu Nilai Tukar, Inflansi, Indeks Stabilitas Politik (ISP) terhadap Indek Harga Saham Gabungan di BEI secara parsial menggunakan fixed effect model. Tabel 3 dapat dilihat nilai probabilitas dari masing-masing variabel bebas yang digunakan, yaitu variabel Nilai Tukar sebesar 0.0015 , lebih kecil dari alfa (0.05). Sehingga dapat disimpulkan bahwa variabel Nilai Tukar berpengaruh terhadap variabel Y (Indek Harga Saham Gabungan di BEI). 
Adapun variabel Inflansi nilai probabilitasnya sebesar 0.5387, probabilitasnya lebih besar dari alfa $(0,05)$ sehingga dapat disimpulkan bahwa variabel Inflansi tidak berpengaruh terhadap variabel $Y$ (Indek Harga Saham Gabungan di BEI). Adapun variabel ISP (Indeks Stabilitas Politik) nilai probabilitasnya sebesar 0.0001 , lebih kecil dari alfa $(0,05)$ sehingga dapat disimpulkan bahwa variabel ISP berpengaruh terhadap variabel Y (Indek Harga Saham Gabungan di BEI). Variabel Nilai Tukar dan ISP nilai probabilitasnya lebih kecil dari alfa $(0,05)$ sehingga dapat disimpulkan bahwa variabel Nilai Tukar dan ISP berpengaruh signifikan terhadap variabel Y (Indek Harga Saham Gabungan di BEI).

Penelitian ini, digunakan tingkat kepercayaan $a=5 \%$, dengan $\mathrm{df}$ $(n-k)=(40-3)=37$ maka diperoleh t-tabel 2.021. Berdasarkan output pada Tabel 3 dapat dilihat bahwa nilai t-statistik Inflansi sebesar 0.621314, yaitu lebih kecil dari t-tabel (2.021). Dilihat bahwa nilai tstatistik Nilai Tukar sebesar 3.463396, yaitu lebih besar dari t-tabel (2.021). Dan Nilai statistik ISP sebesar 4.509454, yaitu lebih besar dari ttabel (2.021). Sehingga dapat disimpulkan bahwa variabel Inflansi tidak berpengaruh terhadap Indek Harga Saham Gabungan di BEI. Variabel Nilai Tukar dan ISP nilai t-statistiknya lebih besar dari t-tabel (2.021). Sehingga dapat disimpulkan bahwa ISP dan Nilai Tukar berpengaruh signifikan terhadap Indek Harga Saham Gabungan di BEI dan variabel Inflansi tidak berpengaruh. Sedangkan Pada Tabel 3 Output prob F statistik diperoleh hasil 0.000000 lebih kecil dari $a=5 \%$, sehingga dapat disimpulkan bahwa semua variabel $x$ (NILAI TUKAR, INFLANSI ISP) berpengaruh secara simultan terhadap variabel $\mathrm{Y}$. Pada Tabel 3 ditunjukkan bahwa nilai $\mathrm{F}$ statistik sebesar 127. 6825, artinya F-statistik lebih besar dari F-tabel (2.84). Sehingga dapat disimpulkan bahwa semua variabel $\mathrm{x}$ berpengaruh signifikan secara simultan terhadap variabel Y.

Berdasarkan hasil regresi sebagaimana yang tertera pada tabel 3, diketahui bahwa nilai koefisien determinasi (Adjusted R-squared) sebesar $0.958703 \mathrm{Hal}$ ini menunjukkan bahwa variasi variabel dependen (Indeks harga saham di BEI) secara simultan dapat dijelaskan oleh variabel independen (NILAI TUKAR, INFLANSI ISP) sebesar $95.8703 \%$ sedangkan sisanya dijelaskan oleh faktor lain di luar variabel yang diteliti.

\section{Hubungan Nilai Tukar Dengan Indek Harga Saham Gabungan Di BEI}

Hasil penelitian ini menunjukkan bahwa Nilai Tukar berpengaruh signifikan pada taraf nyata $5 \%$ dengan nilai probabilitas 0.0015 dan berhubungan negatif dengan nilai koefisien sebesar -1.255034. Hasil penelitian ini menunjukkan bahwa Nilai tukar merupakan variabel makroekonomi yang turut mempengaruhi volatilitas harga saham. Dampak merosotnya nilai tukar rupiah terhadap dolar memungkinkan berpengaruh negatif terhadap pasar modal, mengingat sebagian besar perusahaan 
yang go-public di BEI mempunyai hutang luar negeri dalam bentuk valuta asing. Produk-produk yang dihasilkan oleh perusahaan publik tersebut banyak menggunakan bahan yang memiliki kandungan impor tinggi. Pemerintah mempunyai peran penting untuk meredam melemahnya nilai tukar rupiah, misalnya dengan menaikkan suku bunga SBI. Hasil tersebut sesuai dengan teori dan hasil penelitian-penelitian terdahulu. (Pratikno, 2009) menunjukan nilai tukar berpengaruh negatif signifikan terhadap IHSG. Nilai tukar rupiah terhadap mata uang lainnya berpengaruh terhadap laba suatu perusahaan, karena perusahaan yang menggunakan bahan produksi dari luar negeri akan mengalami peningkatan nilai hutang apabila nilai rupiah terhadap mata uang asing menurun atau terdepresiasi dan Kewal (2012), nilai tukar juga sangat berpengaruh bagi perusahaan yang melakukan ingin melakukan investasi, karena apabila pasar valas lebih menarik daripada pasar modal maka umumnya investor akan beralih investasi ke pasar valas, oleh karena itu perubahan nilai tukar akan berpengaruh terhadap harga saham di pasar modal.

\section{Hubungan ISP dengan Indek Harga Saham Gabungan di BEI}

Hasil penelitian ini menunjukkan bahwa stabilitas politik nasional mempunyai pengaruh secara signifikan pada taraf nyata $5 \%$ dengan nilai probabilitas 0.0001 dan berhubungan positif dengan nilai koefisien 0.067285. . Hasil penelitian ini menunjukkan bahwa investor pasar saham sangat mempertimbangkan kondisi politik nasional dalam memutuskan investasinya, semakin stabil kondisi politik maka akan semakin meningkatkan minat investor untuk berinvestasi di pasar saham, sehingga dapat meningkatkan harga saham. Selain faktor makroekonomi, faktor politik juga merupakan faktor penting pembentuk iklim investasi. Hasil tersebut sesuai dengan teori yang menyatakan bahwa stabilitas politik nasional berpengaruh positif terhadap tingkat investasi, yang dalam hal ini adalah investasi di pasar modal. Hasil penelitian ini juga sesuai dengan penelitian terdahulu. Penelitian yang dilakukan Anggaraini (2012) menunjukkan bahwa peristiwa politik memberikan pengaruh signifikan terhadap harga saham. Trisnawati (2012) dalam penelitiannya menyatakan bahwa peristiwa politik mampu mempengaruhi harga saham. Menurut Trisnawati (2012), peristiwa pemilu 2009 mengakibatkan adanya perbedaan rata-rata return tidak normal antara sebelum dan sesudah pemilu 2009

\section{Hubungan Inflansi dengan Indek Harga Saham Gabungan di BEI}

Hasil penelitian ini menunjukkan bahwa inflasi tidak berpengaruh signifikan pada taraf nyata $5 \%$ dengan nilai probabilitas 0.5807 dan berhubungan positif dengan nilai koefisien sebesar 1.862315 . Hasil tersebut sesuai dengan teori dan hasil penelitian-penelitian terdahulu. Suciningtias dan Khoiroh (2015) dalam hasil penelitiannya menyatakan 
bahwa inflasi berhubungan negatif terhadap harga saham syariah. Hasil yang demikian juga diperkuat oleh penelitian Hafidz dan Setiawan (2015) dan Andi (2017) yang menyimpulkan bahwa inflasi berpengaruh negatif tidak signifikan terhadap harga saham. Kenaikan inflasi menyebabkan kenaikan harga-harga secara umum. Kondisi demikian mampu meningkatkan biaya produksi dan meningkatnya harga bahan baku sedangkan daya beli masyarakat akan semakin melemah. Melemahnya daya beli masyarakat menyebabkan beberapa perusahaan kurang mampu menjual produk perusahaan sehingga menurunkan profitabilitas perusahaan. Menurunnya profit perusahaan dinilai kurang menarik dan kurang menguntungkan bagi investor, sebab return yang akan dibagikan perusahaan kepada pemegang saham juga akan menurun, sehingga investor enggan berinvestasi ke pasar saham. Keadaan ini mampu menyebabkan turunnya harga saham. Selain itu, penurunan profit suatu perusahaan yang disebabkan inflasi juga menyebabkan pemegang saham perusahaan tersebut memutuskan untuk menjual sahamnya. Penjualan saham jika dilakukan secara besar tentu akan menurunkan harga saham.

\section{KESIMPULAN}

Berdasarkan hasil dan pembahasan tentang pengaruh Analisis Stabilitas Politik (Pemilu Presiden) dan Faktor Ekonomi Terhadap Indek Harga Saham Gabungan, Maka dapat ditarik kesimpulan bahwa:

Variabel Nilai Tukar berpengaruh Negatif signifikan terhadap Indek Harga Saham Gabungan. Hasil penelitian ini menunjukkan bahwa Nilai Tukar merupakan variabel makroekonomi yang turut mempengaruhi volatilitas harga saham. Dampak merosotnya nilai tukar rupiah terhadap dolar memungkinkan berpengaruh negatif terhadap pasar modal, mengingat sebagian besar perusahaan yang go-public di BEI mempunyai hutang luar negeri dalam bentuk valuta asing. Produk-produk yang dihasilkan oleh perusahaan publik tersebut banyak menggunakan bahan yang memiliki kandungan impor tinggi.

Variabel inflansi berpengaruh positif tidak signifikan terhadap Indek Harga Saham Gabungan. Kenaikan inflasi menyebabkan kenaikan hargaharga secara umum. Kondisi demikian mampu meningkatkan biaya produksi dan meningkatnya harga bahan baku sedangkan daya beli masyarakat akan semakin melemah. Melemahnya daya beli masyarakat menyebabkan beberapa perusahaan kurang mampu menjual produk perusahaan sehingga menurunkan profitabilitas perusahaan. Menurunnya profit perusahaan dinilai kurang menarik dan kurang menguntungkan bagi investor, sebab return yang akan dibagikan perusahaan kepada pemegang saham juga akan menurun, sehingga investor enggan berinvestasi ke pasar saham.

Variabel ISP berpengaruh positif signifikan terhadap Indek Harga Saham Gabungan hal ini di sebabkan karena investor pasar saham sangat 


\section{JAA}

Vol. 5, No. 2, April 2021

mempertimbangkan kondisi politik nasional dalam memutuskan investasinya, semakin stabil kondisi politik maka akan semakin meningkatkan minat investor untuk berinvestasi di pasar saham, sehingga dapat meningkatkan harga saham.

\section{DAFTAR PUSTAKA}

Anggaraini, Diany Ayudana. (2012). Analisis Pengaruh Kondisi Politik Dalam Negeri Terhadap Abnormal Return Indeks LQ 45 (Studi Kasus Pergantian Kepemimpinan di Indonesia Tahun 1999, 2001, 2004, dan 2009). Tesis tidak dipublikasikan. Jakarta: Fakultas Ekonomi Universitas Indonesia.

Achmad Ath Thobarry. (2008). Analisis Pengaruh Nilai Tukar, Suku Bunga, Laju Inflasi Dan Pertumbuhan Gdp Terhadap Indeks Harga Saham Sektor Properti (Kajian Empiris Pada Bursa Efek Indonesia Periode Pengamatan Tahun 2000-2008 ). Tesis. Program Studi Magister Manajemen Universitas Diponegoro

Anh-Tuan Doan, Thu Phan, Kun-Li Lin. (2020). Governance quality, bank price synchronicity and political uncertainty. Journal Pre-proof. International Review of Economics and Finance. S10590560(20)30086-1.

Anwar, Chairul. (2004). Studi Peristiwa Reaksi Pasar Modal Terhadap Pemilihan Umum Tanggal 5 April 2004 pada Bursa Efek Jakarta. Jurnal Ekonomi dan Bisnis. 2 (9): 98-107

David R. Bowes. (2018). Stock Market Volatility And Presidential Election Uncertainty: Evidence From Political Futures Markets. The Journal of Applied Business Research - January/February 2018 Volume 34, Number 1

Enny Magdalena Saragih. Dr. Isfenti Sadalia, Dr. Amlys Syahputra Silalahi. The Impact of Presidential Election on Abnormal Return, Trading Volume Activity, Security Return Variability in Banking Industries Listed on the Indonesia Stock Exchange. www.ijrrjournal.com E-ISSN: 2349-9788; P-ISSN: 2454-2237

Farhan Ahmed. (2020). Meta-Analysis On American Presidential Election 2016 And American Stock Market. Estudios de economia apicade. 38-1 2020 P P . 1 - 7

Firdausi, Aurora Nur. (2016). Pengaruh Indeks Harga Saham Regional Asean dan Variabel Makroekonomi terhadap Indeks Harga Saham Syariah Indonesia. Jurnal Al-Muzara'ah. 4 (2): 76-96.

Inho Leea, Shiyong Yoob. (2020). Does peace boost stock prices? Evidence from the Korean stock market. Journal of Asian Economics. ASIECO-101247. University, 0674, Seoul, Republic of Korea.

Isaac Marcelina,, Sheryl-Ann K. Stephenb , Fassil Fantac , Mussie Teckleziond. (2018). Research in International Business and 
Finance. Contents lists available at ScienceDirect. org/10.1016/j.ribaf.2018.10.003

Jake Yennaco. (2020). Healthcare Stocks and Presidential Elections. Honors theses and capstones.student scholarship.Universitas of new Hampshire.

Lubos Pastor Pietro Veronesi. (2029). Political Cycles And Stock Returns. Nber Working Paper Series. Political Cycles and Stock Returns Lubos Pastor and Pietro Veronesi NBER Working Paper No. 23184.

Mark Schaub. (2020). A Note on the Early Effects of the Brexit and US Presidential Votes on REITs. International Journal of Economics and Finance; Vol. 12, No. 6; 2020 ISSN 1916-971X EISSN 1916-9728 Published by Canadian Center of Science and Education.

Mohammad Enamul Hoque a, Mohd Azlan Shah Zaidi. (2020). Global and country- specific geopolitical risk uncertainty and stock return of fragile emerging economies. Borsa Istanbul Review. 20-3 197213.

Muhammad Ainnul Wahid. (2018). Analisis Pengaruh Stabilitas Politik Dan Faktor Ekonomi Terhadap Jakarta Islamic Index (JII). Skripsi Jurusan Ekonomi Syariah Fakultas Ekonomi Dan Bisnis Universitas Islam Negeri Syarif Hidayatullah Jakarta

Savva Shanaev, Binam Ghimire. (2018). Is all politics local? Regional political risk in Russia and the panel of stock returns. Journal of Behavioral and Experimental Finance. S2214-6350(18)30149-7

Setiawan, Aziz Budi dan Hafidz Ash-Shidiq. (2015). Analisis Pengaruh Suku Bunga SBI, Uang Beredar, Inflasi, dan Nilai Tukar Terhadap Indeks Harga Saham Jakarta Islamic Index (JII) Periode 2009-2014. Jurnal Ekonomi dan Perbankan Syariah. 3 (2): 25-46.

Sriyana, Jaka. 2014. Metode Regresi Data Panel. Yogyakarta: EKONISIA

Stefan Eichler and Timo Plaga. (2020). The Economic Record of the Government and Sovereign Bond and Stock Returns around National Elections. Journal Pre-proof. S0378-4266(20)30099-6

Suciningtias, Siti Aisiyah dan Rizki Khoiroh. (2015). Analisis Dampak Variabel Makroekonomi Terhadap Indeks Saham Syariah Indonesia. Conference in Business, Accounting, and Management. 2 (1): 398412.

Suramaya Suci Kewal (2012) Pengaruh Inflasi, Suku Bunga, Kurs, Dan Pertumbuhan Pdb Terhadap Indeks Harga Saham Gabungan. Jurnal Econimia Vol 8, No $1>$ Kewal

Triandi, dan Skundita Pratikno. 2009. Peranan Audit Operasional Dalam Meningkatkan Efektivitas Dan Efisiensi Fungsi Pembelian Pada PT. Organ ... 
Trisnawati, Fenny. (2011). Pengaruh Peristiwa Politik Terhadap Perubahan Harga Saham. Pekbis Jurnal. 3 (3): 528-535.

Zhigao Liu a,b , Michael Dunford a , Weidong Liu. (2020). Coupling national geo-political economic strategies and the Belt and Road Initiative: The China-Belarus Great Stone Industrial Park. journal homepage: http://www.elsevier.com/locate/polgeo. Political Geography. 84.102296 